\title{
Analisis Perbandingan Antara Colocation Server Dengan Amazon Web Services (Cloud) Untuk Usabilitas Portal swa.co.id Di PT. Swa Media Bisnis)
}

\author{
Lipur Sugiyanta, Witri Adinda Nur Rakhmah \\ lipurs@unj.ac.id, adindawitri@gmail.com
}

\begin{abstract}
Abstrak
Untuk mendukung usabilitas web portal nya, SWA Media Online menggunakan layanan web hosting Colocation Server dari Wowrack. Layanan Colocation Server dari Wowrack ini memiliki lokasi server fisik atau pusat data di Surabaya, Indonesia. Seiring berjalannya waktu, penggunaan Colocation Server dirasa semakin menghambat perkembangan perusahaan, terbukti dengan melambatnya akses ke web portal swa.co.id. Untuk itu, pada bulan Mei - Juni 2015 SWA Media Online memutuskan berpaling dari Colocation Server ke teknologi cloud terbaru. Pada akhir bulan Juni 2015, SWA Media Online resmi bermigrasi dari colocation ke Amazon Web Services. Dimana server fisik nya berada di Singapura (untuk pelanggan ASEAN). Untuk fitur yang digunakan, hampir sama seperti saat menggunakan colocation yaitu yang sesuai dengan kebutuhan perusahaan. Namun, pada Amazon Web Services memberikan service atau fitur tambahan berupa adanya load balancer, auto scaling, dan bucket atau media penyimpanan. Metodologi yang peneliti terapkan dalam penelitian ini adalah metodologi analisis secara kualitatif. Berdasarkan hasil penelitian, didapatkan hasil bahwa fitur tambahan yang diberikan Amazon Web Services mampu meningkatkan usabilitas portal dalam segi kemudahan dalam kecepatan akses portal. Kecepatan akses web portal meningkat lebih baik dibandingkan saat menggunakan Colocation Server.
\end{abstract}

Kata kunci : Analisis, Perbandingan, Web Hosting, Web Portal, Colocation Server, Cloud Computing, Amazon Web Services, Usabilitas.

\section{Pendahuluan}

Selain menerbitkan majalah dalam bentuk fisik, SWA dalam mengembangkan perusahaannya meluncurkan sebuah web portal dengan alamat swa.co.id. Peluncuran web portal tersebut juga sebagai bentuk usaha untuk lebih dikenal oleh masyarakat dan memudahkan masyarakat untuk mendapatkan informasi yang dibutuhkan. Untuk mendukung web portal nya agar dapat diakses oleh semua orang, SWA Media Online menggunakan layanan web hosting Colocation Server dari Wowrack. Layanan Colocation Server dari Wowrack ini merupakan buatan orang Indonesia, namun kantor pusatnya berada di Amerika. Wowrack memiliki kantor perwakilan di Indonesia yang berada di Surabaya yang juga merupakan lokasi server fisik Colocation milik SWA Media Online.

Seiring berjalannya waktu, penggunaan Colocation Server dirasa semakin menghambat perkembangan perusahaan, terbukti dengan melambatnya akses ke web portal swa.co.id. Untuk itu, pada bulan Mei - Juni 2015 SWA Media Online memutuskan berpaling dari Colocation Server ke teknologi cloud terbaru. Saat itu perusahaan mencoba mencari informasi mengenai teknologi apa yang digunakan web portal besar lainnya untuk memenuhi kebutuhan perusahaan.

Setelah melakukan pencarian informasi, didapatkan bahwa web portal lain seperti detik.com, liputan6.com dan web portal besar yang ada di Indonesia, ternyata banyak yang sudah beralih ke teknologi cloud menggunakan layanan dari Amazon Web Services (AWS). Setelah mengetahui hal tersebut, SWA Media Online memutuskan untuk menggunakan layanan Amazon Web Services mengikuti web portal besar terdahulu lainnya yang sudah menggunakan jasa tersebut.

Pada akhir bulan Juni 2015, SWA Media Online resmi bermigrasi dari Colocation ke Amazon Web Services. Dimana server fisik nya berada di Singapura (untuk pelanggan ASEAN). Kelebihan pada Colocation Server terletak pada biaya layanan nya yang murah dan adanya customer support yang berada di Jakarta sehingga memudahkan jika terdapat kendala. Kekurangan Colocation Server terletak pada bandwidth yang terbatas. Sedangkan kelebihan Amazon Web Services terletak pada bandwidth unlimited yang mencapai 500Mbps, serta adanya fitur tambahan berupa load balancer, auto scaling, dan bucket atau media penyimpanan. Kekurangan Amazon Web Services terletak pada biaya yang lebih mahal dah tidak adanya perwakilan customer support di Jakarta. 
Dari penjelasan diatas, penulis ingin mengetahui layanan server yang mana yang mampu meningkatkan usabilitas dari segi kemudahan dalam kecepatan akses yang lebih baik untuk portal swa.co.id milik SWA Media Online dalam periode satu tahun pada tahun 2015 melalui data dari pengamatan langsung dan juga hasil wawancara. Oleh karena itu, penulis tertarik melakukan penelitian untuk dijadikan sebagai skripsi dengan judul :

"Analisis Perbandingan antara Colocation Server dengan Amazon Web Services (Cloud) untuk Usabilitas Portal swa.co.id di PT. SWA Media Bisnis".

\section{Kerangka Teoritik}

\subsection{Web Hosting}

Web Hosting adalah salah satu bentuk layanan jasa penyewaan tempat di internet yang memungkinkan perorangan ataupun organisasi menampilkan layanan jasa atau produknya di web/situs internet (Puspitosari, 2010:2). Ada beberapa jenis layanan hosting yaitu, shared hosting yaitu menggunakan server hosting bersama-sama dengan pengguna lain, satu server dipergunakan oleh lebih dari satu nama domain. Artinya dalam satu server tersebut terdapat beberapa akun yang dibedakan antara akun satu dan lainnya dengan username dan password. VPS atau Virtual Private Server dikenal sebagai Virtual Dedicated Server merupakan proses virtualisasi dari lingkungan software sistem operasi yang dipergunakan oleh server. Hal tersebut memungkinkan untuk menginstall sistem operasi yang dapat berjalan diatas sistem operasi lain.

Namun, teknologi virtualisasi memungkinkan setiap akun harus diperlakukan sebagai mesin sendiri dengan sumber daya sendiri yang berdedikasi dan sistem operasi), Dedicated Server (hosting yang menyediakan Dedicated Server dengan sumber daya yang didedikasikan untuk klien tunggal) dan Colocation Server (server yang dititipkan ke suatu tempat yang aman untuk menyimpan server yang memiliki standar dan keamanan penyimpanan server yang memadai).

\subsection{Colocation Server}

Colocation Server menyediakan layanan untuk menyimpan atau menitipkan server di Data Center yang memiliki standar keamanan fisik dan infrastuktur, seperti: kestabilan arus listrik, UPS, power generator, air temperature control, kestabilan akses internet, CCTV, dan petugas keamanan yang akan bekerja setiap hari dalam memantau server anda. Biasanya server ini disimpan dalam rak atau kabinet. Layanan yang diberikan pada perusahaan perusahaan jasa penyedia Colocation Server pada umumnya memberikan layanan yang bersifat Unmanaged Service, dimana dukungan teknis diberikan sampai pada jaringan. Penyedia jasa dalam hal ini hanya melakukan instalasi jaringan dan pemasangan server pelanggan pada rak data center.

\subsection{Cloud Computing}

Cloud computing telah menjadi salah satu topik yang paling dibahas oleh pengamat IT beberapa tahun terakhir. Hal ini didasarkan pada banyak kemajuan di industri IT selama dekade terakhir, dan memberikan peluang yang signifikan bagi perusahaan untuk efisiensi waktu ke pasar dan mengurangi biaya. Dengan cloud computing, perusahaan dapat mengkonsumsi komputasi dan penyimpanan sumber daya bersama daripada membangun, mengoperasikan, dan memperbaiki infrastruktur sendiri.

Peter Meel dan Timothy Grance (2011:6) mendefinisikan Cloud Computing sebagai sebuah model yang memungkinkan adanya penggunaan sumber daya (resource) secara bersama-sama dan mudah, menyediakan jaringan akses dimana-mana, dapat di konfigurasi, dan layanan yang digunakan sesuai keperluan (on demand). Menurut National Institute of Standards and Technology (NIST), Cloud computing memiliki 5 karakteristik (Alex, 2012:2), yaitu :

a. On-demand self-service. Pengguna diberikan kemampuan komputasi secara sepihak, seperti server time dan network storage yang dibutuhkan tanpa perlu adanya interaksi dengan penyedia jasa.

b. Broad network access. Kapabilitas layanan dari cloud provider tersedia lewat jaringan dan bisa diakses oleh berbagai jenis perangkat, seperti smartphone, tablet, laptop, workstation, dsb.

c. Resource pooling. Pengguna umumnya tidak memiliki kuasa untuk penempatan lokasi dari resource.

d. Rapid elasticity. Kapabilitas dari layanan cloud provider bisa dipakai oleh cloud consumer secara dinamis berdasarkan kebutuhan. Cloud consumer bisa menaikkan atau menurunkan kapasitas layanan. Kapasitas layanan yang disediakan ini biasanya tidak terbatas, dan service consumer bisa dengan bebas dan mudah memilih kapasitas yang diinginkan setiap saat.

e. Measured service. Tersedia layanan untuk mengoptimasi dan memonitor layanan yang dipakai secara otomatis. Dengan monitoring sistem ini, kita bisa melihat berapa resources komputasi yang telah dipakai, seperti: bandwidth, storage, processing, jumlah pengguna aktif, dsb. Layanan monitoring ini sebagai bentuk transparansi antara cloud provider dan cloud consumer.

\subsection{Amazon Web Services}

Amazon Web Services adalah sekumpulan layanan-layanan berbasis Cloud Computing yang di sediakan oleh Amazon sejak tahun 2002. Amazon.com sebelumnya lebih terkenal dengan toko 
buku online-nya. Meski demikian, beberapa tahun yang lalu (sekitar tahun 2005), Amazon mengembangkan dirinya menjadi AWS (Amazon Web Services) yang menyediakan layanan komputasi awan, di mana setiap fungsi yang ada di dalamnya bisa diakses dengan panggilan Web Services. Layanan - layanan Amazon Web Services dapat dikelompokkan menjadi 5 bagian besar (Varia dan Mathew, 2014:10), yaitu :

a. Layanan Komputasi: Layanan ini di khususkan untuk memberi infrastruktur bagi pengguna yang ingin menggunakan Amazon untuk melakukan komputasi seperti server atau clustered server.

- Amazon Elastic Compute Cloud (EC2) adalah platform komputasi berupa virtual computer yang dapat di kustomisasi maupun di kembangkan dengan menggunakan prinsip cluster dan load balance.

- Amazon Elastic Map Reduce adalah layanan yang membantu dalam analisis data seperti data penjualan, data stok, data server log dan lain-lain. Yang kemudian data-data tersebut dapat di konversikan menjadi sebuah hasil analisis yang dapat digunakan dalam sistem pengambil keputusan.

- Elastic Load Balancing adalah layanan yang menjadi satu paket dengan Amazon EC2, di mana layanan ini berfungsi untuk menyeimbangkan beban antara instansiinstansi yang kita miliki dalam Amazon EC2.

b. Layanan Penyimpanan: Layanan yang memberi infrastruktur untuk pengguna yang ingin menggunakan Amazon untuk melakukan penyimpanan. Layanan ini dapat digunakan oleh user sebagai media backup maupun Content Delivery Network (CDN).

- Amazon Simple Storage Service (S3) adalah layanan media penyimpanan media internet. Amazon S3 dapat menjadi shared folder maupun Network Attached Storage. Infrastruktur dapat dilihat pada gambar 2.1.

- Amazon Elastic Block Store (EBS) adalah tempat penyimpanan di sitem operasi Amazon EC2. EBS ini juga merupakan media yang disimpan diatas Amazon S3

- AWS Storage Gateway adalah layanan penyimpanan yang disediakan Amazon untuk perusahaan berskala besar.

- Amazon CloudFront adalah layanan untuk distribusi konten ke berbagai lokasi server Amazon.

c. Layanan Basis Data: Layanan ini di khususkan untuk basis data, di mana basis data kita tersebut disimpan di cloud, dan dapat di akses dari mana saja secara aman, cepat dan terpercaya.

- Amazon Relational Database Service (RDS) adalah layanan server basis data di mana data dan server akan berada di cloud yang akan menjamin kualitas koneksi, kecepatan, keamanan dan kehandalan. Kita dapat memiliki aplikasi server yang kita mau seperti: MySQL, Oracle dan SQL Server.

- Amazon DynamoDB adalah layanan server basis data yang NoSQL dengan kualitas koneksi, kecepatan, keamanan dan juga mudah di setup dan konfigurasi.

- Amazon SimpleDB adalah layanan server basis data yang NoSQL yang mirip dengan Amazon DynamoDB namun dengan skala yang lebih kecil.

- Amazon ElastiCache adalah layanan memory cache di atas cloud.

d. Layanan Jaringan: Layanan ini di khususkan untuk mengatur jaringan antara layanan-layanan yang di dalam cloud maupun di luar cloud.

- Amazon Route 53 adalah layanan untuk domain name server (DNS).

- Amazon Virtual Private Cloud (VPC) adalah layanan untuk membuat private cloud dengan menggabungkan layanan-layanan yang ada dalam Amazon Web Services.

e. Layanan Aplikasi: Layanan aplikasi ini desediakan oleh Amazon untuk melengkapi layananlayanan yang lainnya. Layanan-layanan ini seperti aplikasi pencarian, aplikasi notifikasi, aplikasi email server, aplikasi workflow.

- Amazon CloudSearch adalah layanan untuk menggabungkan fungsi pencarian dari Amazon Cloud Search dengan aplikasi yang kita miliki.

- Amazon Simple Workflow Service (SWF) adalah layanan alur kerja proses bisnis atau mengelola infratruktur cloud di dalam Amazon Web Service.

- Amazon Simple Queue Service (SQS) adalah layanan yang menyediakan sistem antrian pesan/intruksi dari satu aplikasi ke aplikasi lainnya.

- Amazon Simple Notification Service (SNS) adalah layanan yang menyerupai mailing list, di mana kita dapat melakukan notifikasi kepada klien, nasabah maupin penggunapengguna lainnya dengan mengirimkan Email dan SMS

- Amazon Simple Email Service (SES) adalah layanan Email yang memperbolehkan menggunakan email server cloud untuk mengirimkan email dengan aman dan cepat.

\subsection{Amazon Web Services}

Usabilitas menurut ISO (International Standart Organization) adalah tingkat dimana sebuah produk bisa digunakan oleh pengguna tertentu untuk mencapai tujuan tertentu dengan efektif, efisien, dan memperoleh kepuasan dalam konteks penggunaannya (9241:11, 1998). Usabilitas didefinisikan melalui lima komponen, yaitu : 


\section{a. Learnability}

Learnability menjelaskan tingkat kemudahan pengguna untuk memenuhi tugas-tugas dasar ketika pertama kali mereka melihat/menggunakan hasil perancangan (website, program, aplikasi).

b. Efficiency

Efficiency menjelaskan tingkat kecepatan pengguna dalam menyelesaikan tugas - tugas setelah mereka mempelajari hasil perancangan (website, program, aplikasi).

\section{c. Memorability}

Memorability menjelaskan tingkat kemudahan pengguna dalam menggunakan rancangan (website, program, aplikasi) dengan baik, setelah beberapa lama tidak menggunakannya.

\section{d. Errors}

Errors menjelaskan jumlah error yang dilakukan oleh pengguna, tingkat kejengkelan terhadap error dan cara memperbaiki error.

e. Satisfaction

Satisfaction menjelaskan tingkat kepuasan pengguna dalam menggunakan rancangan. Sebuah web dengan usabilitas yang buruk akan ditinggalkan oleh penggunanya.

Dari kelima komponen usabilitas diatas, yang dimaksud peneliti dalam penelitian ini adalah kemudahan dalam kecepatan akses. Dimana hal tersebut masuk kedalam poin efisiensi.

\section{Metodologi}

Pendekatan penelitian ini menggunakan pendekatan kualitatif. Dimana pendekatan ini sangat cocok untuk penelitian tentang riset yang bersifat deskriptif dan cenderung menggunakan analisis, sesuai dengan tema penelitian ini yang akan menganalisis Colocation Server dengan Amazon Web Services. Penelitian kualitatif merupakan penelitian yang menghasilkan data deskriptif berupa kata-kata tertulis atau lisan dari orang-orang dan perilaku yang diamati (Bodgan dan Taylor, 1975, diacu dalam Moleong, 2012:4).

\section{Hasil Penelitian}

\subsection{Hasil Pengamatan Langsung}

\subsubsection{Spesifikasi Perangkat}

a. Colocation

1) Intel i3 $21003,12 \mathrm{GHz}$

2) 4 GB RAM

3) 1000 GB SATA

4) Bandwith lokal : Unlimited IIX, Bandwith Internasional : $512 \mathrm{Kbps}$

5) OS Linux

\section{b. AWS}

1) High Frequency Intel Xeon Processor with Turbo Up to $3,3 \mathrm{GHz}$

2) Dual core processor

3) 8 GB RAM

4) 30 GB SSD

5) PIOPS - Optimized

6) OS Linux
7) Load balancing

8) Bucket

9) Auto scaling

\subsubsection{Topologi Server}

a. Topologi Saat Menggunakan Colocation Server

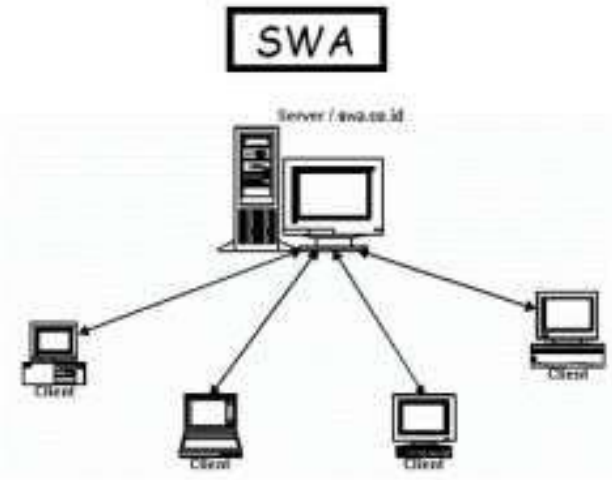

Gambar 4.1. Topologi Colocation Server

b. Topologi Saat Menggunakan AWS

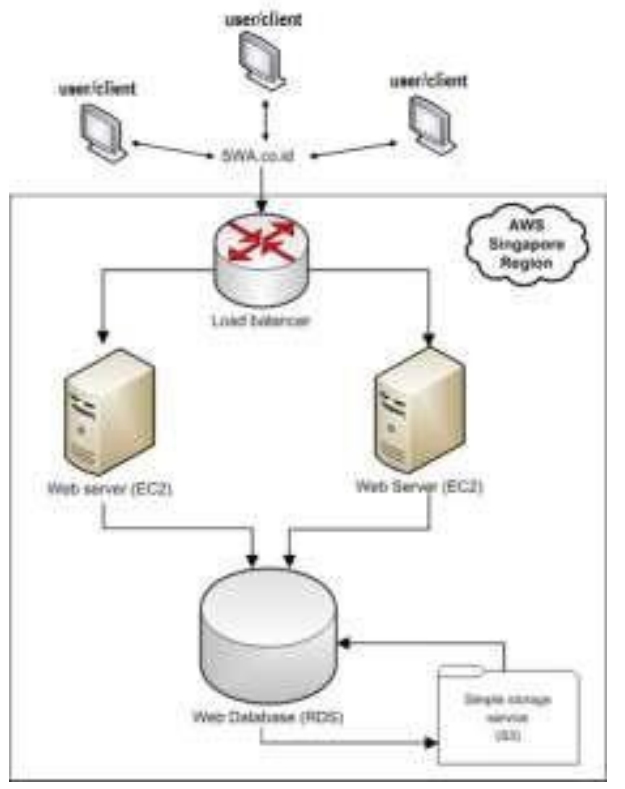

Gambar 4.2. Topologi Amazon Web Services 


\subsubsection{Hasil Pengukuran dengan Google Analytic}

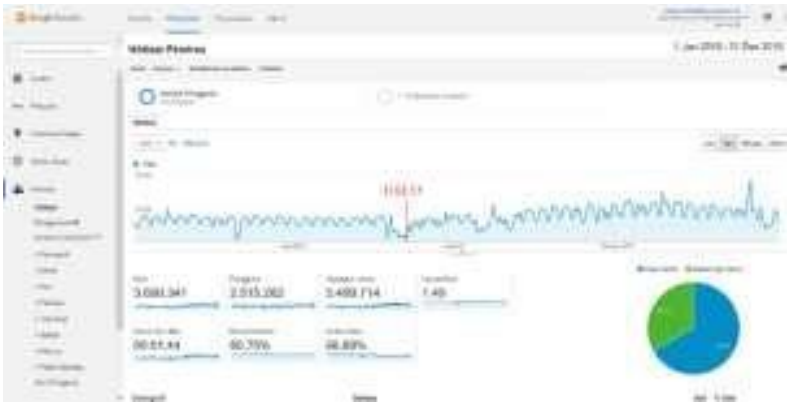

Gambar 4.3. Hasil Pengukuran Berdasarkan per Hari

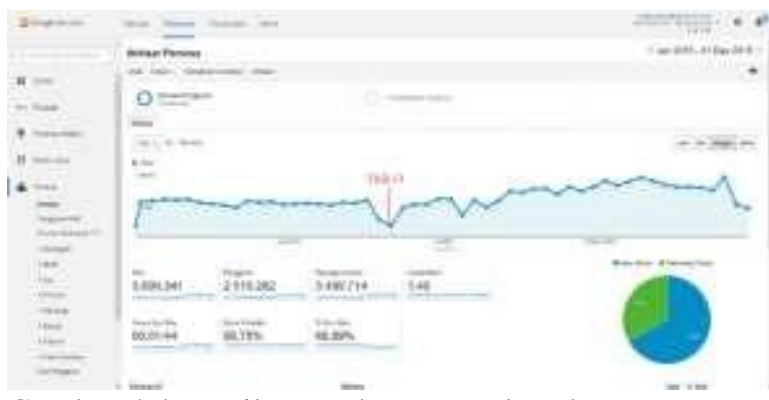

Gambar 4.4. Hasil Pengukuran Berdasarkan per Minggu

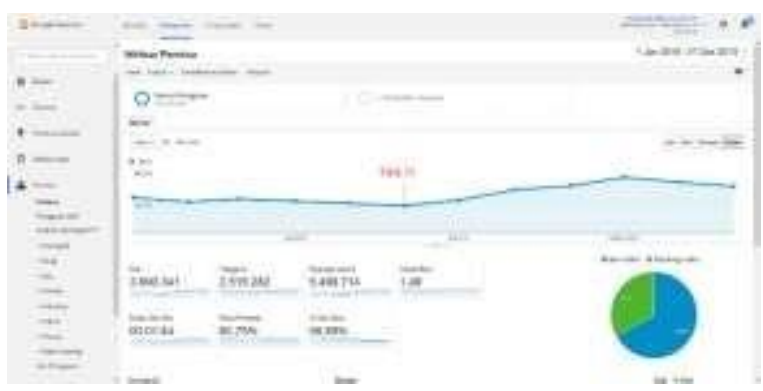

Gambar 4.5. Hasil Pengukuran Berdasarkan per Bulan

\section{Kesimpulan dan Saran}

\subsection{Kesimpulan}

Berdasarkan hasil penelitian di PT. SWA Media Bisnis (SWA) mengenai Analisis Perbandingan antara Colocation Server dengan Amazon Web Services (Cloud) untuk Usabilitas Portal swa.co.id di PT. SWA Media Bisnis, maka dapat disimpulkan bahwa :

1. Layanan Colocation Server tidak memberikan fitur-fitur tambahan kepada SWA. Sedangkan Amazon Web Services memberikan fitur-fitur tambahan, fitur tersebut diantaranya adalah load balancing, auto scaling, dan bucket. Load balancing memiliki fungsi untuk membagi beban yang masuk ke sejumlah resource yang seragam. Dari sisi SWA dan user, load balancing membantu portal swa.co.id menjadi lebih cepat untuk di akses, dikarenakan beban akses terbagi ke sejumlah resource. Auto scaling memiliki fungsi untuk menaikkan dan menurunkan kapasitas cloud resources sesuai dengan keadaan yang telah ditentukan. Dari sisi SWA, auto scaling bermanfaat untuk meminimalisir biaya yang keluar, dari sisi user fitur ini tidak bisa dirasakan secara langsung. Fitur bucket atau simple storage merupakan fitur yang dapat digunakan untuk menyimpan dan mengambil sejumlah data dimanapun, dan kapanpun. Dari sisi SWA manfaat fitur ini adalah mampu menyimpan berbagai file dalam jumlah besar. Dari sisi user, fitur ini mampu membantu user mendapatkan file yang diinginkan melalui portal dengan cepat.

2. Layanan Colocation Server memberikan bandwidth yang terbatas. Untuk akses lokal hanya $512 \mathrm{Kbps}$ untuk akses internasional unlimited up to 500Mbps. Sedangkan Amazon Web Services memberikan bandwith unlimited untuk akses lokal dan internasional up to 500Mbps. Hal tersebut memberikan kemudahan dalam kecepatan akses ke web portal bagi SWA dan user.

\subsection{Saran}

Dalam memilih layanan server, diperlukannya analisis kebutuhan perusahaan, dan analisis spesifikasi yang akan memenuhi kebutuhan perusahaan tersebut. Sehingga perusahaan mampu menentukan layanan mana yang sesuai dengan kebutuhan perusahaan baik itu dari segi sistem, sumber daya manusia (teknisi ahli), maupun finansial.

\section{Daftar Pustaka:}

Anastasia. 2015.

https://www.linkedin.com/pulse/colocationserver-anastasia-su?redirectFromSplash=true (diakses pada 27 Juni 2016 pukul 17:00)

Anonim. https://blog.idkeyword.com/memahamiistilah-umum-pada-google-analytics/ (diakses pada 27 Juni 2016 pukul 16:40)

Annisa. 2015. https://blog.idwebhost.com/tipskeren/apa-itu-colocation-server-dan-mengapaharus-dipilih-untuk-web-hosting/ (diakses pada 27 Juni 2016 pukul 17:20)

Anonim. http://blog.lintasarta.net/article/colocationserver-indonesia-murah/ (diakses pada 27 Juni 2016 pukul 20:10)

Anonim.

https://id.wikipedia.org/wiki/Amazon_Web_Se rvices (diakses pada 27 Juni 2016 pukul 17:40) Anonim. http://kbbi.web.id/lambat (diakses pada 28 Juni 2016 pukul 20:30)

Anonim. 2015.

http://socs.binus.ac.id/2015/09/18/usability-vs- 
user-experience/ (diakses 18 Juli 2016 pukul 19.00)

Anonim.

http://triplefareaftkj.blogspot.co.id/2015/05/pen gertian-hosting-hosting-adalah.html (diakses pada 27 Juni 2016 pukul 16:40)

Anonim. https://penalaran-

unm.org/artikel/penelitian/409-uji-keabsahandata-dalam-penelitian-kualitatif.html (diakses pada 23 April 2016 pukul 11:25)

Anonim.

http://www.ilmuwebhosting.com/2015/02/peng ertian-colocation-server.html (diakses pada 27 Juni 2016 pukul 18:00)

Anonim

https://www.webhostingterbaik.org/2016/06/ap a-itu-web-hosting.html (diakses pada 28 Juni 2016 pukul 14:40)

Azalia, Syifa. 2013. Studi tentang Tingkat Kesadaran Hukum Pedagang Pasar Mingguan dalam Membayar Retribusi. Bandung: UPI

Bonar, S.K. 1981. Tehnik Wawancara. Jakarta: Bina Akasara

Budiyanto, Alex. 2012. Pengantar Cloud Computing. Cloud Indonesia

Devie.

https://devieafriani.blogspot.co.id/2010/12/prin sip-prinsip-usability.html (diakses pada 26 Juni 2016 pukul 00:04)

Dr. Basrowi, M.Pd. \& Dr. Suwandi, M.Si.,. 2008. Memahami Penelitian Kualitatif. Jakarta: Hardi. Rineka Cipta

https://viallyhardi.wordpress.com/2010/02/18/u sability/ (diakses pada 26 Juni 2016 pukul 00:39)

Hidayat. 2010.

https://bangkitkansemangat.wordpress.com/201 0/06/26/web-usability/ (diakses pada 27 Juni 2016 pukul 18:00)

Irdiana Malik, Andita dan Edi Irawan, S.Pd.., M.IKom, Rahmat. 2013. Strategi Produksi Program Icip-Icip di Binus Tv dalam Meningkatkan Kualitas Program. Jakarta: Undergraduate thesis, BINUS

Iskandar. 2009. Metodologi Penelitian Kualitatif. Jakarta: Gaung Persada.

Lexy J. Moleong. 2012. Metode Penelitian Kualitatif, Bandung: Rosda Karya
Meel, Peter dan Grance, Timothy. 2011. The NIST Definition of Cloud Computing. United States: National Institute of Standards and Technology

Miles, Mattew B dan A. Michael Huberman. (2007) Analisis Data Kualitatif, Buku sumber tentang metode - metode baru. Jakarta: Universitas Indonesia Press

Nielsen, Jakob. 1994. Usability Engineering. San Diego: Academic Press, Inc

Puspitosari, Heni A. 2010.Membangun Website Interaktif dengan Adobe Creative Suite 5 Tingkat Dasar. Yogyakarta: PT Skripta Media Creative

Robbins, David. 2009. 20 Maret 2010. Cloud Computing Explained. https://www.pcworld.com/article/164933/cloud _computing.html (diakses pada 28 Juni 2016 pukul 13:40)

Rosa, A.S dan M. Shalahuddin. 2014. Rekayasa Perangkat Lunak Terstruktur dan Berorientasi Objek. Bandung: Informatika Bandung

Shinta. http://sraportofolio.blogspot.co.id/2013/03/kele bihan-dan-kekurangan-cloud-computing.html (diakses pada 28 Juni 2016 pukul 18:00)

Varia, Jinesh dan Matthew Sajee. 2014. Overview of Amazon Web Services

Zaenal. 2012.

https://zaenalkhayat.wordpress.com/2012/10/0 7/kecepatan-akses-internet-pengertian-danfaktor-yang-mempengaruhinya/ (diakses pada 28 Juni 2016 pukul 20:00) 